Editorial

\title{
GEIS: una década de historia
}

Desde que a principios del año 1994 y tras una reunión realizada en Valencia, unos pocos oncólogos españoles se reunieran y convinieran en la necesidad de comenzar a trabajar de forma conjunta, en los tratamientos de tumores tan poco frecuentes y heterogéneos como son los Sarcomas de partes blandas, han sucedido muchas cosas para el Grupo.

La filosofía del Grupo español para investigación en Sarcomas (GEIS) siempre ha sido la de un grupo abierto, donde pueden integrarse oncólogos interesados en el tratamiento de los sarcomas, así como todos los profesionales de diferentes áreas relacionados con el diagnóstico y tratamiento de estos tumores tan diversos. Desde que en una de las primeras reuniones del Grupo éramos doce los Hospitales integrados, hemos pasado a que sean más de 60 los que en este momento constan como socios, incluido más de un Hospital portugués; si bien es verdad que la actividad es muy diversa entre unos y otros Centros.

Inicialmente GEIS fue planteado como un grupo dedicado a fomentar la investigación clínica en sarcomas, posteriormente se ha añadido la faceta de divulgación tanto al público como a los profesionales dedicados al tratamiento, a través de creación de guías clínicas, conferencias de consenso y reuniones científicas de carácter internacional periódicas. Durante estos años de andadura, se han desarrollado múltiples proyectos llevando el trabajo del Grupo a los más distinguidos foros de la Oncología mundial con presencia continuada en AS$\mathrm{CO}^{1-22}$, así como la culminación de muchos de los ensayos en forma de publicaciones en las revistas internacionales más prestigiosas ${ }^{23-31}$.

Pero uno de los logros más interesantes es sin duda el intento de establecer unas pautas de líneas de trabajo, a través de estudios fase III, aleatorizados en primera y segunda línea de tratamiento de los sarcomas avanzados, y donde persiste la controversia sobre las estrategias de tratamiento más adecuadas (monoterapia vs poliquimioterapia, dosis adecuada, secuencia de fármacos, etc) en el tratamiento de esta enfermedad. Asimismo se están llevando a cabo ensayos en colaboración con diferentes Grupos internacionales como la EORTC, ISG, FSG, ASG, con especial énfasis en los estudios de neoadyuvancia y adyuvancia (tanto en sarcomas de partes blandas como el GIST), estudios especialmente complejos por el elevado número de pacientes necesarios para su realización.

Otro de los objetivos del grupo es el potenciar los estudios de investigación básica, donde cada uno de los ensayos que se lleven a cabo, contengan un estudio traslacional de factores biológicos y pronósticos. Para ello contamos con la colaboración de un Comité de Patología que asesora y colabora en el desarrollo de los posibles proyectos. Fruto de esta colaboración, recientemente se ha publicado un estudio que incluyó 168 pacientes con GIST $(\mathrm{KIT}+)$ resecado radicalmente y mayor de $2 \mathrm{~cm}$ analizando factores pronóstico clínicos, patológicos y moleculares, estableciendo que entre otros factores, las delecciones que afectan a los codones 557 a 558 tienen influencia en el intervalo a la recaida ${ }^{30}$.

Una ambición que tenemos es el potenciar la creación de bancos de tumores hospitalarios de sarcomas, que permitan facilitar los estudios traslacionales a través de una coordinación centralizada.

Contando con la colaboración de todos los Centros integrantes del GEIS, se ha llevado a cabo un registro nacional de sarcomas. Se accede vía on-line y en este momento hay más de 2000 casos censados. Este hecho, ha despertado gran interés en otros grupos internacionales, ya que podría tratarse del primer registro europeo en este tipo de tumores. La información disponible es importante, dado que es la base que nos permite plantear 
la factibilidad de los estudios clínicos a la hora de su diseño. Además, de los datos disponibles tendremos información de la patología que se atiende en los hospitales del grupo, problemas diagnósticos y datos específicos de factores pronóstico, supervivencia, etc.

Disponemos también de un Registro Nacional prospectivo e informatizado on-line de pacientes con GIST y está en fase de elaboración avanzada el Registro Nacional de tumores óseos.

La página web ( http://www.grupogeis.com) puede ser visitada tanto en español como en inglés. Dada la necesidad de colaboración con otros grupos internacionales, la web es una buena manera de divulgar la actividad del grupo y posiblemente compartir proyectos futuros. A través de ella se pueden conocer los ensayos que el grupo tiene en marcha. Dispone de un acceso para el público en general con interés y por supuesto con acceso restringido para todos los miembros componentes de GEIS.

Desde diciembre de 1997, somos una entidad jurídica en forma de asociación científica con Estatutos propios, accesibles en la web.

Desde estas páginas, queremos hacer una invitación formal para que todos los profesionales en relación con la Oncología, conozcan la historia del Grupo y les animamos para que sean parte activa del mismo, colaborando con sus ideas y aportando sus conocimientos y como no, participando formalmente en el desarrollo de los actuales ensayos en marcha y en los que vayan elaborándose en un futuro, ya que posiblemente con la llegada de las nuevas dianas moleculares, podamos llevar a cabo estudios interesantes y eficaces para nuestros pacientes.

\section{P. Escudero Emperador, X. García del Muro, A. López Pousa}

Grupo GEIS

www.grupogeis.com

\section{Bibliografía}

1. López-Pousa A. First-line high dose ifosfamide in patients with advanced soft-tissue sarcoma. A phase II study of the spanish group for research on sarcomas. 21 St ESMO Congress.Vienna, Noviembre 1996.

2. Buesa JM, López-Pousa A, Antón A, Martín J, García del Muro X, Bellmunt J, Poveda A, Escudero P. Phase II trial of first-line high-dose Ifosfamide in advanced soft tissue sarcoma (STS) patients. Poster. 33nd ASCO. Denver, Mayo 1997. Proc Am Soc Clin Oncol 1997; 16:498a.

3. López-Pousa A, Montalar J, Buesa JM, Maurel J, Martín J, Cassinello J, Sevilla I, de las Peñas R, Cruz J, Balañá C, García del Muro X, Poveda A. High-Dose Ifosfamide and Doxorubicin in advanced previously untreated soft tissue sarcoma patients. a phase II study of the Spanish Group for Research in Sarcomas (GEIS). 4th CTOS Annual Scientific Meeting. Vancouver, November 1998.

4. López-Pousa A, Montalar J, Buesa JM, Maurel J, Martín J, Cassinello J; Sevilla I; de las Peñas R, Cruz J, Balañá C. First-line doxorubicin and high-dose ifosfamide (DHI) in advanced soft tissue sarcoma (STS) patients. A phase II study of the Spanish Group for Research on Sarcomas. Abstract 564. 23rd ESMO Congress. Atenas, Noviembre 1998

5. López-Pousa A, Buesa JM, Montalar J, Martín J, Maurel J, García del Muro X, de las Peñas R, Cruz J, Cassinello J, Sevilla I, Balañá C, Casado A, Bover I, Paredes A, Carles J, Poveda A. Phase II trial of Doxorubicin and High-dose Ifosfamide in advanced previously untreated soft tissue sarcoma patients. a study of the Spanish Group for Research in Sarcomas (GEIS). Poster Discussion. 36th ASCO. Atlanta, mayo 1999. Proc Am Soc Clin Oncol 1999; 18:544a.

6. Poveda A, López-Pousa A, Martín J, Buesa JM, Balañá C, Menéndez D. Liposomal Doxorubicin (Caelyx) in advanced soft tissue sarcoma patients. A phase II study of the Spanish Group for Research in Sarcomas (GEIS). Comunicación. 36th ASCO. Atlanta, mayo 1999. Proc Am Soc Clin Oncol 1999; 18:553a.

7. Buesa JM, Teijido PG, Galbe M, López-Pous A, García del Muro X, Martín J, Antón A, Montalar J, de las Peñas R, Cruz J, Escudero P, Fra J, Menéndez D, Poveda A. Nephrotoxicity of continuous infusion ifosfamide. A study of the Spanish Group for research on Sarcomas (GEIS). Reunión de la C.T.O.S., Washington, Octubre 1999

8. Buesa JM, Teijido PG, Galbe M, López-Pousa A, García del Muro X; Martín J, Antón A, Montalar J, de las Peñas R, Cruz J, Escudero P, Fra J, Menéndez D, Poveda A. Nephrotoxicity of continuous infusion ifosfamide. A study of the Spanish Group for Research on Sarcomas (GEIS)". Abstract 0037. 5th CTOS Congress. Arlington, Octubre 1999. 
9. López-Pousa A, Buesa JM, Montalar J, Martín J, Maurel J, García del Muro X, de las Peñas R, Cruz J, Cassinello J, Sevilla I, Balañá C, Casado A. First-line Doxorubicin and scalated High-dose Ifosfamide in advanced soft tissue sarcoma patients a phase II study of the Spanish Group for Research in Sarcomas (GEIS). Comunicación-Poster- Sesion. 36th ASCO New Orleans, Louisiana, mayo 2000.

10. López-Pousa A, Buesa JM, García del Muro X, Manuel J, Balañá C, Casado A, Bellmunt J, Poveda A, Martín J, Martínez-Trufero J, de las Peñas R, Bover I. Sequential High-dose Doxorubicin and High-dose Ifosfamide in advanced previously untreated soft tissue sarcomas of the adult. A multicenter phase II study of the Spanish Group for Reseach in Sarcomas (GEIS). Poster - Discussion. 37th ASCO Annual Meeting. San Francisco, mayo 2001. Proc Am Soc Clin Oncol 2001;20:353a.

11. García del Muro X, López-Pousa A, Buesa JM, Martín J, Bover I, Escudero P, Casado A, Martínez-Trufero J, Maurel J. Temozolomide as a 6-week continuous oral schedule in advanced soft tissue sarcomas: a phase II study of the Spanish Group for Reseach in Sarcomas (GEIS). Poster - Discussion. 37th ASCO Annual Meeting. San Francisco, mayo 2001. Proc Am Soc Clin Oncol 2001;20:354a.

12. López-Pousa A, Buesa JM, García del Muro X, et al. Sequential high-dose doxorubicin (Dx) and High dose Ifosfamide (IF) in advanced previosly untreated soft tissue sarcoma of the adult (STS). A multicenter phase II study of the Spanish Group for Research on Sarcomas (GEIS). Proc Am Soc Clin Oncol 2001; 20:353.

13. García del Muro X, López-Pousa A, Buesa JM, et al. Temozolomide as a 6 week coninuous oral schedule in advanced soft tissue sarcomas: A phase II study of the Spanish Group for Research on Sarcomas (GEIS). Proc. Am Soc Clin Oncol 2001; $20: 1412$.

14. Garcia del Muro X, López-Pousa A, Buesa JM, Martín J, Poveda A, Bover I, Escudero P, Martínez-Trufero J, Casado A. Temozolomide as a 6-week continuous oral schedule in advanced soft tissue sarcoma: a phase II trial of the spanish group for research on sarcomas (GEIS). 2001 CTOS Annual Meeting Posters- Medical Oncology.

15. Maurel J, Buesa JM, López-Pousa A, García del Muro X, Martínez-Trufero J, de las Peñas R, Escudero P, Piera JM, Martín J, Casado A, Sevilla I, Balañá C, Bover I, Montalar J, Poveda A, Cassinello J, Cruz J, Carles J, Camps C, Bellmunt J. High-dose ifosfamide (HDIF) based regimens in advanced soft tissue sarcoma patients. An analysis of prognostic factors: A study of the Spanish Group for Research on Sarcomas (GEIS). Proc Am Soc Clin Oncol 2002;21 (407a):a-1627.

16. Buesa JM, Teijido PG, Fra J, et al. Treatment of ifosfamide (IFOS) encephalopathy with intravenous thiamine. Poster Discussion. Proc Am Soc Clin Oncol 2002;21:409,a.

17. Martín J, López-Pousa A, Bover I, Sevilla I, Cruz J, Buesa JM, Escudero P, Blanco R, Poveda A, Casado A, García del Muro X, Maurel J, Piera JM, Maestu I, Casado S, Carles J, González de Sande LM, Montalar J, Martínez-Trufero J, de las Peñas R, Rifa J. Malignant Gastointestinal stromal tumors and uterine sarcomas: differences in prognostic factors for survival. A clinical approach. Study of the Spanish Group for Research in sarcomas (GEIS). Poster Discussion. Proc Am Soc Clin Oncol 2002; $21\left(411^{\mathrm{a}}\right.$ ):a-1641.

18. López-Pousa A, Buesa JM, Martín J, Casado A, Balañá C, García del Muro X, Poveda A. Phase I/II trial of Doxorubicin and dose escalation prolonged infusion Gemcitabine as first line treatment in advanced soft tissue sarcomas. A study of the Spanish Group for Research in Sarcomas (GEIS). General Poster Session. Proc. Am Soc Clin Oncol 2003; 22(825):3317.

19. Buesa JM, Fra J, López-Pousa A, Losa R, Mareque B, Sierra M, Una E, Blay P. Phase I trial of Dacarbacine (DTIC) and prolonged infusion Gemcitabine in patients with soft Tissue sarcoma. Poster Discussion. Proc Am Soc Clin Oncol vol 2003;22:3296.

20. Martín J, Poveda A, Llombart-Bosch A, Ramos R, García del Muro X, Martínez-Trufero J, de Juan A, Maurel J, Losa F, Buesa JM. Prognostic value of pathologic variables and mutations type in patients with complete surgical resection of gastrointestinal stromal tumors (GIST). A GEIS study. General Poster Session. Proc Am Soc Clin Oncol 2004;22:9029.

21. López-Pousa A, Buesa JM, Casado A, García del Muro X, Poveda A, Maurel J, Martín J, Balañá C, Martínez-Trufero J, Martín J, Poveda A, Llombart-Bosch A, Ramos R, García del Muro X, Martínez-Trufero J. Doxorubicin (DXR) and prolonged infusion gemcitabine (GMC) as first-line treatment in advanced soft tissue sarcomas (STS). A phase II trial of the Spanish Group for Resarch in Sarcomas (GEIS). General Poster Session. Proc Am Soc Clin Oncol 2004;22:9033.

22. García del Muro X, Fra F, Martínez-Trufero J, Sevilla I, Escudero P, Cruz J, Martín J, Casado A, Arrazubi V, Buesa JM. Temozolomide in the treatment of gynecological leiomyosarcoma: A Spanish Group for Resarch in Sarcomas (GEIS) study. Poster Discussion. Proc Am Soc Clin Oncol 2005;22:9030.

23. Buesa JM, Fra J, Antón A, López-Pousa A, Martín J, García del Muro X, Escudero P, Casado A, Poveda A. Activity of doxorubicin ofá high-dose ifosfamide in adult patients with advanced ofá tissue sarcoma: a study of the Spanish Group for Research on Sarcomas (GEIS). Ann Oncol. 1998 Jul;9(7):783-5.

24. Buesa JM, López-Pousa A, Martín J, Antón A, García del Muro X, Bellmunt J, Arranz F, Valenti V, Escudero P, Menéndez D, Casado A, Poveda A. Phase II trial of first-line high-dose ifosfamide in advanced soft tissue sarcomas of the adult: a study of the Spanish Group for Research on Sarcomas (GEIS). Ann Oncol. 1998 Aug;9(8):871-6.

25. Maurel J, Fra J, López-Pousa A, García del Muro X, Balañá C, Casado A, Martín J, Martínez-Trufero J, de las Peñas R, Buesa JM; Spanish Group for Research on Sarcomas (GEIS). Sequential dose-dense doxorubicin and ifosfamide for advanced soft tissue sarcomas: a Phase II trial by the Spanish Group for Research on Sarcomas (GEIS). Cancer. 2004 Apr 1;100(7):1498-506.

26. Maurel J, Buesa JM, López-Pousa A, García del Muro X, Quintana MJ, Martín J, Casado A, Martínez-Trufero J, de las Peñas R, 


\section{P. Escudero Emperador y cols.}

Balañá C. Salvage surgical resection after high-dose ifosfamide (hdif) based regimens in advanced soft tissue sarcoma (asts): a potential positive selection bias - a studi of Spanish group for research on sarcomas (GEIS). J Surg Oncol. 2004 Oct 1;88(1):44-9.

27. Buesa JM, Losa R, Fernández A, Sierra M, Esteban E, Díaz A, López-Pousa A, Fra J. Phase I clinical trial of fixed-dose rate infusional gemcitabine and dacarbazine in the treatment of advanced soft tissue sarcoma, with assessment of gemcitabine triphosphate accumulation. Cancer. 2004 Nov 15;101(10):2261-9.

28. Blay JY, Bonvalot S, Casali P, Choi H, Debiec-Richter M, Dei Tos AP, Emile JF, Gronchi A, Hogendoorn PC, Joensuu H, Le Cesne A, McClure J, Maurel J, Nupponen N, Ray-Coquard I, Reichardt P, Sciot R, Stroobants S, van Glabbeke M, van Oosterom A, Demetri GD. Consensus meeting for the management of gastroinstestinal stromal tumors. Report of the GIST Consensus Conference of 20-21 March 2004, under the auspices of ESMO. Ann Oncol. 2005 Apr;16(4):566-78.

29. García del Muro X, López-Pousa A, Martín J, Buesa JM, Martínez-Trufero J, Casado A, Poveda A, Cruz J, Bover I, Maurel J. A phase II trial of temozolomide as a 6-week, continuous, oral schedule in patients with advanced soft tissue sarcoma: a Spanish group for research on sarcomas (GEIS) study. Cancer. 2005 Aug 30;104(8):1706-12.

30. Martín J, Poveda A, Llombart-Bosch A, Ramos R, López-Guerrero JA, García del Muro X, Maurel J, Calabuig S, Gutierrez A, González de Sande JL, Martínez-Trufero J, de Juan A, Laínez N, Losa F, Alija V, Escudero P, Casado A, García P, Blanco R, Buesa JM, Carles J, Bellmunt J, Gómez A, Meana A, Sevilla I, Maestu I, Valentí V, Balañá C, Carrasco JL, Cubedo R, Cassinello J, Molano F, Rubió J, Bover I, Cruz J. Deletions Afecting Codons 557-558 of the c-KIT Gene Indicate a Poor Prognosis in Patients With Completely Resected Gastrointestinal Stromal Tumors: A Study by the Spanish Group for Sarcoma Research (GEIS). J Clin Oncol. 2005 Sep 1; 23(25):6190-8.

31. Poveda A, López-Pousa A, Martín J, García del Muro J, Bernabé R, Casado A, Bañala C, Sanmartín O, Menéndez MD, Escudero P, Cruz J, Belyakova E, Menéndez D, Buesa JM. Phase II clinical trial with pegylated liposomal doxorubicin $\left(\mathrm{CAELYX}^{\circledR} / \mathrm{Doxil}^{\circledR}\right)$ and quality of life evaluation (EORTC QLQ-C30) in adult patients with advanced soft tissue sarcomas. A study of the Spanish Group for Research in Sarcomas (GEIS). Sarcoma 2005 Sep/Dec; 9(3/4):127-32. 